IFN Working Paper No. 678, 2006

\title{
Israel M. Kirzner: An Outstanding Austrian Contributor to the Economics of Entrepreneurship
}

Robin Douhan, Gunnar Eliasson and Magnus Henrekson 


\title{
Israel M. Kirzner: An Outstanding Austrian Contributor to the Economics of Entrepreneurship*
}

\author{
Robin Douhan $^{1,3}$, Gunnar Eliasson ${ }^{2}$ and Magnus Henrekson ${ }^{3}$
}

26 October 2006

\begin{abstract}
Israel M. Kirzner is the 2006 winner of The International Award for Entrepreneurship and Small Business Research. In this essay, we present and evaluate his main contributions to the economics of entrepreneurship.

The focus is on how Kirzner defines the entrepreneurial function. In order to better understand his theory, we posit Kirzner's notion of an entrepreneur in the Austrian tradition. In so doing we emphasize that this concept opens up different perspectives as compared to the neoclassical theoretical framework. The three areas of economic policy, justice and freedom and economic growth are discussed. We also show why the Kirznerian entrepreneur makes these issues relevant.

Perhaps most importantly, Kirzner has made the Austrian School intelligible for non-Austrians. By bridging the chasm between Austrian and mainstream thinking, the crucial role of entrepreneurship and the individual entrepreneur has become visible to a much broader audience.
\end{abstract}

Keywords: Austrian economics; Economic development; Entrepreneurship; Small business economics.

JEL Codes: B49; B52; B53; O31.

${ }^{1}$ Department of Economics

University of Uppsala

P.O: Box 513

SE- 75120 Uppsala

Phone: +46-8-471 1590

Fax: +46-8-471 1478

Robin Douhan@nek.uu.se
${ }^{2}$ Department of Industrial Economics and Management

Royal Institute of Technology (KTH)

SE-100 44 Stockholm

Phone: +46-8-790 6803

Fax: +46-8-622 6914

Gunnar.Elias@telia.com
${ }^{3}$ Research Institute of Industrial Economics P. O. Box 55665 SE-102 15 Stockholm Phone: +46-8-665 4502 Fax: +46-8-665 4599 Magnus.Henrekson@riie.se

\footnotetext{
* Gunnar Eliasson and Magnus Henrekson are members of the Prize Committee for The International Award for Entrepreneurship and Small Business Research. The Prize is awarded by the Swedish Foundation for Small Business Research (FSF) and the Swedish Board of Industrial and Technical Development (NUTEK). An important aim with this prize is to attract broader attention to this research field. A precondition for choosing the winner of the award is that the research for which the award has been granted is a significant contribution to the theory and empirical understanding of entrepreneurship and the importance of entrepreneurship, new firm formation and small businesses in economic development. Besides the honor, the Prize consists of USD 50,000. It has been awarded annually since 1996. Previous winners include Zoltan Acs, Howard Aldrich, David Audretsch, William Baumol, Paul Reynolds and David Storey. More information about the Prize and previous winners is available at http://www.fsf.se/intaward.html. We are grateful for useful comments and suggestions from Johan Almenberg, Mikael Stenkula and Anders Nordberg on an earlier version of this essay.
} 


\section{Introduction}

It is [the] entrepreneurial element that is responsible for our understanding of human action as active, creative and human rather than passive, automatic and mechanical. (Kirzner 1973, p. 35)

A free society is fertile and creative in the sense that its freedom generates alertness to possibilities that may be of use to society; a restriction on the freedom of a society numbs such alertness and blinds society to possibilities of social improvement. By the very nature of the damage such restriction wreaks, its harmful effects on social welfare may not be able to be noticed, measured or specified (Kirzner, 1979, p. 239).

The Swedish Foundation for Small Business Research (FSF) and the Swedish Board of Industrial and Technical Development (NUTEK) have given their 2006 International Award for Entrepreneurship and Small Business Research to Israel M. Kirzner. In this article, we present and evaluate the contributions of the Prize winner to the economics of entrepreneurship.

Kirzner has become known as one of the most vocal and strongest critics of the neoclassical preoccupation with equilibrium outcomes (Kirzner, 1982). But Kirzner's attitude has never been one of outright rejection. On the contrary, we will argue that one of his greatest contributions has been to bring the Austrian analysis more in line with mainstream economics. Today, such a prominent member of the so-called mainstream as Josh Lerner at Harvard Business School uses Kirzner's writings in his teaching.

But also mainstream economics has changed dramatically in recent decades, to the extent that some have proclaimed the death of neoclassicism (Colander, 2000). Others have proposed that recent developments in mainstream economics, notably a greater focus on bounded rationality, rule following, institutions, cognition and evolutionary aspects, have brought Austrian economics closer to the mainstream (Koppl, 2006). Although Kirzner's work starts out from the other side of the neoclassical-Austrian divide, we will argue that his work has also indirectly contributed to the development within mainstream economics.

Despite these recent developments, our discussion will to a large extent revolve around neoclassicism and Kirzner's seemingly ambivalent relation to that theory. Here, the entrepreneur is central. One of Kirzner's great insights was that key concepts in the Austrian 
tradition also provided a natural theoretical habitat for the entrepreneur. The most important of these concepts are subjectivity, ignorance and economic mistakes; all of which can be traced back to Carl Menger, the father of the Austrian school (Kirzner, 1978). Therefore, it will be important to outline the historical context from which Kirzner has developed his thinking.

Kirzner's theory can be related to neoclassicism by saying that the entrepreneur is someone who is alert to out-of-equilibrium profit opportunities. As such, the Kirznerian entrepreneurs can be seen as substitutes for the Walrasian auctioneer. But this change in the nature of the auctioneer has far-reaching consequences. Thus, even though the main body of Kirzner's academic work has been revolving around the entrepreneur, he has ventured into a number of other fields, notably the methodology of economics, the role of the policymaker and economic justice and freedom.

When neoclassical economists have tried, during the last 20 years or so, to bring the entrepreneur into their growth models, it has almost always been the Schumpeterian entrepreneur. An important example is $R \& D$ driven innovations functions (e.g. Aghion and Howitt, 1992; Segerstrom, 1991), and also the growing field of so-called evolutionary modeling (e.g. Nelson and Winter, 1982, 2002). The function of the Schumpeterian entrepreneur is to disturb an existing circular flow, or equilibrium. But since Kirzner questions the notion of an existing equilibrium, he also rejects the assumption on which Schumpeter builds his theory. Therefore, we must also ask what the function of the Kirznerian entrepreneur is with respect to economic growth.

In what follows we will address most of these issues. Besides trying to cover as many of Kirzner's contributions as possible, there is another rationale for presenting such a broad array of issues. Many of the questions Kirzner raises on methodology, policy and justice are absent in the neoclassical framework. But Kirzner's theory of entrepreneurship changes the point of reference. In doing so, it does not only change the answers but also the questions raised. From Kirzner's perspective, the issue of freedom, justice and a fair society are crucial for understanding economic reality.

In the next section, we position Kirzner within the Austrian tradition and outline some fundamental aspects of his analysis. Section 3 introduces the Kirznerian entrepreneur and 
section 4 discusses the implications for economic policy. We then turn to the issues of justice and freedom in section 5. In section 6, we relate Kirzner's thinking to other theories of growth. We conclude by returning to what we consider to be Kirzner's greatest contribution, namely to bridge the gap between Austrian and neoclassical thinking.

\section{The Austrian Legacy}

It is into [a] bewildering mass of empirical data that the economic point of view throws a ray of light. It enables us to grasp an element that does introduce a measure of explanation into social phenomena. (Kirzner 1960, §7.60)

Israel M. Kirzner is the most prominent contemporary member of the school of Austrian economists. Broadly defined, this school once included Carl Menger, Eugene von BöhmBawerk, Joseph Schumpeter, Ludwig von Mises, Frank Knight and Friedrich von Hayek as towering figures. However, the marginal revolution and neoclassical economics soon gained ground over the loosely structured early Austrian school. Since then, the Austrian school has for a long time been classified as a heterodox approach. However, in recent years, Kirzner has become the leader of what has been called "the Austrian revival” (Gloria-Palermo, 1999). The Kirznerian entrepreneur has proved to embody a fruitful combination of different strands of thinking within the Austrian tradition. To understand Kirzner's writings, it is important to posit him against the legacy of Menger and against his more recent predecessors, Ludwig von Mises and Friedrich von Hayek.

As is often the case, what to an outsider might look like a fairly homogenous tradition is on closer inspection much more diverse. In particular, the main schism within the Austrian school can probably be derived from conflicting views about how to deal with the legacy of Menger's concepts of subjectivity and ignorance (Kirzner, 1995). Some Austrians, notably Ludwig Lachmann (1976), have argued that if these concepts are taken seriously, the idea of a possible equilibrium must be abandoned (Vaughn, 1992). If people are ignorant of so much in the environment in which they act and if there is no such thing as "objective data" on which to act, then how can we propose that their actions are moving the economy toward a state of equilibrium? In fact, how can we even conceptualise the notion of equilibrium?

Kirzner has strongly resisted this radical interpretation of subjectivity. Part of his rejection is 
due to Mises and part is due to Hayek (Binenbaum, 1995). The part emanating from Mises (1949) is the notion of the entrepreneur. The entrepreneurial element in action is the element that makes individuals capable of coping with (genuine) uncertainty and limited knowledge. This is not to say that the entrepreneur in one stroke overcomes the limitations implied by subjectivity. And it is not to say that entrepreneurs cannot be mistaken and ventures fail. But, in small steps, the actions of entrepreneurs tend to make the market more coordinated. Here, Kirzner draws on Hayek's (1937) notion of coordination and gradual learning. Vernon Smith's (1962) work is also worth mentioning as the starting point for another strand of research along these lines.

Menger's recognition of ignorance and economic mistakes in his economic theory and his emphasis of understanding rather than formal analysis meant a rejection of the notion of full information equilibrium. As we have seen, Kirzner does not agree with the most radical interpretation of this rejection. But why has he embraced it in a weaker form? In his early work, Kirzner (1960) criticizes Lionel Robbins’s (1932) view of economics - that economics is the "science which studies human behavior as a relationship between ends and scarce means which have alternative ends”. According to Kirzner, this view reduces economics to a formal and mechanical means-end calculus. By positing given ends, this view overlooks what is to Kirzner the crucial element of economics, namely that agents act purposefully. The foundation of economic science is that individuals act so as to improve their position and do so purposefully. This is the economic point of view.

The definition made by Robbins narrows this view significantly, and rules out many kinds of economically relevant analyses. This is a point forcefully stated in the introductory chapter to Kirzner's most influential work, the 1973 monograph Competition and Entrepreneurship. In equilibrium, means and ends are already given, and there is no scope for analyzing how they are determined. Since this is exactly the entrepreneurial function, there is no place for the entrepreneur. Moreover, Kirzner stresses that competition loses its meaning in an equilibrium framework. In equilibrium, competition has ceased, it is reduced to a technical tool convenient when solving mathematical models. But nothing is said about competition as a process.

It is a highly complex issue to disentangle in what sense Kirzner rejects equilibrium analysis. From what has been said above, it follows that it is rejected more because of its shortcomings 
as a theoretical framework than because of its failure to correspond to empirical reality. It can be argued that no single (known or future) universal theory of economics is capable of addressing more than a restricted range of economic problems (Eliasson, 1996). Social theory is always problem dependent and therefore, economic analysis entails the choice of the appropriate model for the particular problem chosen. In this sense, the Austrian school and Kirzner offer a framework for analyzing many problems that cannot be dealt with when using a neoclassical toolbox.

\section{The Kirznerian Entrepreneur}

The entrepreneur's activity is essentially competitive. And thus competition is inherent in the nature of the entrepreneurial market process. Or, to put it the other way around, entrepreneurship is inherent in the competitive market process. (Kirzner 1973, p. 17)

We have seen that the notion of equilibrium is important for Kirzner. However, the main emphasis is put on the dynamic and rivalrous process that pushes the economy towards equilibrium rather than the state of equilibrium. It is this process that provides a habitat for the entrepreneur; the entrepreneur is not someone who operates in a world of given prices and information. Instead, the entrepreneur is the agent that purposively changes prices, quantities and other "data" (Kirzner, 1997). "Alertness" is the key attribute of the Kirznerian entrepreneur; an alertness to hitherto unnoticed opportunities. In the simplest case, this entrepreneur coincides with the arbitrageur, who recognizes a profit-opportunity in the price differentials in different markets. Viewed in this way, it is easy to fit the Kirznerian entrepreneur into an equilibrium framework. As pointed out by Vaughn (1992), this is simply a more carefully stated version of the story that a countless number of economics professors tell their students when showing how markets attain equilibrium. But that is the story of maximization given means and ends; Kirzner's emphasis on "alertness" precedes that story. The implications of this will become clear when we discuss the role of the policymaker and entrepreneurship and growth.

The alertness to disequilibria must be coupled with another important characteristic, namely that an entrepreneurial act is always carried out under (genuine) uncertainty. Uncertainty is distinct from calculable risk. Nor is it appropriate to characterize the entrepreneur as someone who is engaged in a systematic search process (Kirzner, 1997). We have already seen that the 
kind of uncertainty referred to is best understood as resulting from a subjectivist approach. Now, the entrepreneurial element of action is what makes the individual able to tackle this uncertainty:

Entrepreneurship in individual action consists in the endeavor to secure greater correspondence between the individual's future as he envisages it and his future as it will in fact unfold [...] Scope for entrepreneurship is provided by the uncertainty of the future $[\ldots]$ In the absence of entrepreneurial alertness it is only sheer chance that can be responsible for successful action. (Kirzner 1985, p. 58)

This quotation seems to imply that the capacity of alertness completely shields the entrepreneur from making mistakes. Here, it is important to recognize the level of abstraction at which Kirzner carries out his analysis. First, the notion of an entrepreneur is slightly misleading since Kirzner refers to an element in human action (or a specific function) rather than particular individuals or entities. For instance, as we will see later, although this element is distinct from the financial function, both can be embodied in the same individual. Second, the entrepreneurial element is present in all human action (Kirzner, 1973). One way of understanding this is that in a setting where the individual acted under genuine uncertainty and ignorance of many of the surrounding circumstances, the maximizing agent would fail to make any decision at all. The plethora of possible states and her awareness of uncertainty would put her in a state of apathy. The view that all action to a smaller or greater degree contains an entrepreneurial element makes it easier to understand the possibility of mistakes. To the extent that an action is entrepreneurial, the agent lifts himself above the veil of ignorance. Alertness is the guide towards a desirable outcome.

This entrepreneur who brings the economy towards equilibrium is usually contrasted to the Schumpeterian entrepreneur who disrupts existing equilibria (Kirzner, 1999). This difference is better understood if innovations are introduced. A key characteristic of Schumpeter's entrepreneur is the boldness and resolve that enables him or her to introduce innovations despite social resistance and skepticism (Schumpeter, 1934). These characteristics do not appear in the Kirznerian entrepreneur. In fact, Kirzner (1999, p. 13) writes:

If [the entrepreneur] has not seen that opportunity in so shining a light that it drives him to its implementation in spite of the jeering scepticism of others, and in spite of the possibility of its ultimate failure-then he has not really "seen" that opportunity.

Here it appears that the characteristics that Schumpeter ascribed to the entrepreneur are not 
needed. According to Kirzner, what is essential to the entrepreneurial act is not boldness, selfconfidence and courage but a kind of vision. In practice, Kirzner admits that such a clear entrepreneurial insight that would dispel every trace of doubt is virtually impossible. Once more, we must bear in mind the level of abstraction of Kirzner's analysis and that the entrepreneurial element is only present to some degree in real actions. It is also important to see that Kirzner's main interest is to pinpoint the essence of the economic function of the entrepreneurial act, not to put it in a social context.

A good illustration of the difference vis-à-vis Schumpeter is found in Kirzner (1999). Here, he discusses the introduction of automobiles and the effects of this on the horse-carriage industry. His analysis diverges sharply from that of Schumpeter. According to Kirzner, it is not correct to say that the introduction of automobiles disrupted an existing equilibrium. On the contrary, the market was at a severe disequilibrium at the time when automobiles were introduced because too many resources were allocated to the obsolete horse-carriage industry.

Attempts have been made to fuse Kirznerian and Schumpeterian entrepreneurs. For instance, Holcombe (1998) and Fu-Lai Yu (2001) explain growth as a combination of adaptive and disruptive movements by Kirznerian and Schumpeterian entrepreneurs, respectively. The discrepancy in analytical level and approach has led others to doubt that such a fusion is possible (e.g. Glancey and McQuaid, 2000, p. 75).

\section{The Role of the Policymaker}

To the extent that [government policies] suspend or inhibit the market process, they are obstructing a process of discovery without offering any substitute for it. Let us not forget that the market process has the function of alerting market participants to opportunities which nobody has expected. To initiate governmental policies to grapple with externalities is, in effect, to pretend knowledge which no one can, in principle, honestly claim to possess. (Kirzner 2000, p. 82)

In his brief 1982 article on entrepreneurship in economic growth, Kirzner asks: "How do we discover what needs to be done, when this has not yet been perceived?” Can the government act as an entrepreneur? Should it even try? Is this an invitation to the government to act? To the early Austrians, the answer would have been no. For them, the role of the government 
already at that time was hugely overestimated. The purposeful individuals ruled, or rather should rule, and centralization was anathema. Many of the institutions that facilitated market processes were not really the creation of government, they argued, but had been spontaneously created in the market and then been monopolized by the government, most often to the detriment of their functionality. Menger's (1892) analysis of the spontaneous origin of money is still a well-known reference. How about Israel Kirzner, who has lived through the Keynesian revolution and experienced the centralized thinking embodied in the neoclassical model?

Kirzner (1985, chapter 2) provides a concise summary of his view on government interventions in the free market. The most important point was made already in Kirzner (1973, p. 231ff), where he discussed Demsetz's (1969) “Nirvana fallacy”. As argued by Kirzner, standard welfare economics views policy as a choice between an ideal, known norm and an existing "imperfect” (institutional) arrangement. The ideal norm is assumed to be known to the policymaker. Hence, as Pelikan (1988) observes, there will be no way for the market to beat a centralized policymaker. The central planner will always win the theoretical contest. But the ideal norm, or optimum allocation, is not always known. Indeed, in Kirzner's writings, it is imperative that Nirvana is unknown, and not even knowable. The role of the entrepreneurs is to push the economy in the direction of a possible Nirvana.

To put the question bluntly, can Soviet-style central planners be good entrepreneurs? One problem with central planning that is commonly mentioned is that a social planner lacks the computational power to gather and process all necessary information. No single actor, asserted Hayek (1945), is capable of this. But the market works differently, through a process of coordinating the bits and pieces of knowledge scattered throughout the economy and to “communicate information”. In this respect, Hayek's market process far outperforms the planner. The largest problem, though, and the one that Kirzner emphasizes, is that there does not exist an equilibrium to compute. There is information that is not only unknown to the planner, but that is still unknown to the individual agents - these are the entrepreneurial opportunities. Therefore, the question is who is most able to discover these opportunities: a central planner or millions of agents with entrepreneurial abilities.

There may certainly be innovations in the Soviet Union, Kirzner argues. But he (1982, p. 275) warns us that we must not commit the fallacy of "glorifying innovation for its own sake", 
because without the market guidance of profit and prices, we cannot know if innovations are "socially worth while”. In a planned economy agents act, not on market incentives but on the directives and incentives from higher levels of the hierarchy. In effect, superior bureaucrats make the entrepreneurial decisions about which opportunities are important to heed. But what guides their judgment about what to reward? The answer must be the orders from still higher levels in the bureaucracy. Besides drastically reducing the number of entrepreneurial decisions, the error-correcting market process is completely circumvented in the socialist hierarchy. There is nothing per se that contradicts that centralized planners can introduce innovations. The chief problem is instead to ensure that the innovations are socially beneficial, and if not to find ways of correcting judgment. Another problem that Kirzner (1985) mentions is that since profit incentives are largely absent in the government sector, the process of discovery of new opportunities will be hampered and this sector will lag behind in productivity.

A similar analysis is Kirzner (2000), where the analysis is framed by the concepts of "inner" and "outer" limits to the market. The inner limits are drawn up by market failures, i.e. respects in which the market fails to perform optimally. These would constitute a bound on what the market could achieve if left to itself. Outer limits are defined by institutions, notably private property rights and freedom and enforceability of contracts. Kirzner questions the notion of inner limits and, in particular, that this can be used as a justification for government involvement. The reason is that it rests on studying an economy against the benchmark of a social optimum or equilibrium. But, as we have seen, Kirzner rejects the idea of a social planner who could outperform the market. However, government involvement can be justified on the grounds of outer limits, although Kirzner is careful to emphasize that many of these institutions have an ethical foundation and they often change through an evolutionary process rather than abrupt interventions.

After Baumol's (1990, 2002) contributions, it is natural to ask if inappropriate institutions can channel the entrepreneurial potential to non-productive uses. To the best of our knowledge, Kirzner does not address this issue, but according to his definition of entrepreneurship, all forms of rent seeking that do not involve an element of discovery are excluded. Furthermore, the close relation between the entrepreneur, freedom of entry and the competitive process indicates that the possibility of unproductive or destructive entrepreneurship is not a major concern for Kirzner. What Kirzner does say is that entrepreneurship is a resource which, 
under appropriate circumstances, notably freedom of entry, can be tapped at zero cost. This follows from Kirzner's view that entrepreneurship is not a resource; hence, there is no opportunity cost associated with the "use" of entrepreneurship. It is essentially dynamic and hence cannot be added to capital and labor in growth equations (e.g. Kirzner, 1973, 1985).

\section{On Freedom and Justice}

Entrepreneurship does not consist of grasping a free ten-dollar bill which one has already discovered to be resting in one's hand; it consists in realizing that it is one's hand that it is available for the grasping... The discovery of a profit opportunity means the discovery of something obtainable for nothing at all. No investment at all is required; the free ten-dollar bill is discovered to be already within one's grasp (Kirzner, 1973, p. 47, 48, italics in original)

In the previous section, we saw that Kirzner sides with the Austrian tradition in his skepticism towards government involvement in markets. But his defense of freedom goes even deeper. He maintains that the neoclassical framework is incapable of accounting for the role of freedom in a proper way (Kirzner, 1979). In that framework, removal of an option might mean two things. Either it is a lower ranked option in which case the individual is not affected at all, or it is a preferred option in which case the individual's welfare is impaired. In both cases, the individual is free to choose among the remaining options. However, according to Kirzner, the real infringement of freedom occurs earlier, before ends and means are determined. The removal of an option restricts the range within which this decision can be made and therefore, there is more to free choice than feasibility today. There is claimed to be a "fertility of freedom"; an option that cannot be utilized today may nevertheless induce people to strive for a position where it can be attained it in the future. This has important social implications over and beyond the utility flowing from the provision of goods of a higher preference order.

The second topic of this section, justice of the free market, is a theme that runs through much of Kirzner's writings. To understand Kirzner's position, we must once more begin with his notion of an entrepreneur who discovers new opportunities, which have hitherto been unnoticed. These opportunities were "utterly unknown" and not "known to be knowable" (Kirzner, 1997), which is the underlying premise in the neoclassical model with information 
costs (Stiglitz, 1994). By his discovery, the entrepreneur has not only reallocated a given amount of resources but has, in effect, expanded it. This provides the ethical justification for private property; new possibilities are exploited in order to raise the social product. Naturally, factors of production should be paid compensation, but the entrepreneur has a legitimate claim to the residual since without him, no production would have occurred (Kirzner, 1979). According to Kirzner, the reward to the entrepreneur cannot be put on an equal footing with compensation to factors of production; in fact, as we have seen, entrepreneurship is not even a resource. He goes as far as saying that the entrepreneur's initiative implies that "[he] has produced the whole product entirely on his own” (ibid., p. 194, italics in original).

Burczak's (2002) critique sheds some more light on this “finders-keepers" defense of profits. His first line of critique draws on Stiglitz and Weiss' (1981) argument that financial markets work imperfectly. Hence, not everyone has the option of becoming an entrepreneur. Moreover, the visibility of many opportunities are conditional on the possession of resources. The main thrust of Kirzner's (2002) response to this critique is that it may be very difficult to disentangle the entrepreneurial and the financial function. In practice, it is not (financially) feasible for everyone to become an entrepreneur, in the sense of becoming a business owner. But, argues Kirzner, the distinction between entrepreneur and financier is still theoretically sound, and it is the creative aspect of the entrepreneurial element that gives rise to excess (supranormal) profits.

Burzak's other line of criticism is that the workers who partake in production can never be void of responsibility and creativity. Hence, the entrepreneur is not the only one who should be rewarded for these functions. A longer example presented in Kirzner (1973, p. 57ff) provides an answer that parallels the one in Kirzner (2002). Suppose A owns a gun and hires a hunter B to put it to use. Now, A must certainly pay B the market wage for hunter services. But what if $\mathrm{B}$ possesses an exceptional alertness to good hunting grounds and that, consequently, he delivers much more output to A than the market wage implies? Kirzner presents two possibilities. Either B is not sufficiently alert to his own virtues as a hunter, in this case it is A who is the entrepreneur who has been able to notice B's capacity and put it to use. Or, B is himself able to realize his ability and captures the additional opportunities himself, either by hiring a gun or by withholding the above market wage output from A. 


\section{The Role of the Entrepreneur in Economic Growth}

The entrepreneurial spirit, the potential for discovery, is always waiting to be released. Human ingenuity is irrepressible and perennial, and its release requires an environment free from special privileges or blockages of new entrants. For the successful allocative functioning of the market, and for the stimulation of dynamic growth, the entrepreneur must not be taken for granted. (Kirzner, 1985, p. 92)

In his comprehensive treatise Entrepreneurship, Perception, Opportunity and Profit (1979), Kirzner devotes one chapter to entrepreneurship and development. He begins by observing the lack of understanding of the role of the entrepreneur in economic development as a "yawning gap” (p. 107). Siding with Baumol (1968), he observes that the entrepreneur has virtually disappeared from economic theory and that (now quoting Leibenstein, 1968) "received theory of competition gives the impression that there is no need for entrepreneurship". And, as we have seen, there is indeed no role to play for the Kirznerian entrepreneur in the neoclassical framework. But how can we understand the Kirznerian entrepreneur from a growth perspective?

It is here appropriate to refine Kirzner's view of the notion of equilibrium. To simply say that equilibrium has meaning for Kirzner as a goal, as something the economy tends towards, is somewhat too simplistic. The example in section 3 with automobiles and the horse-carriage industry reveals that Kirzner's analysis is more dynamic, since new opportunities are introduced. Kirzner (1992) uses the concepts of Underlying Variables (UV) and Induced Variables (IV) to explain his concept of a market process. UVs are preferences, resources and technological possibilities. IVs are prices, methods of production and output quantities. In mainstream economics, Kirzner argues, IVs are completely determined by UVs. And according to radical subjectivists (see Lachmann, 1976), IVs and UVs cannot at all be separated. Kirzner stands somewhere in between these opposing views. He writes (1999, p. 43):

If we wish to analyse the market process it is therefore most useful to conduct mental experiments against the imagined background of unchanging UVs. In full reality, of course, the market process never does proceed in pure form. Rather, what we encounter over time is a mass of changes in IVs that reflect, in addition, the continual changes in the UVs. 
At first, this might be interpreted as evidence that long-run growth, in which the UVs change, is not what Kirzner is interested in. Here, we must be careful not to commit the fallacy of equating a theory of growth with the neoclassical theory of growth. Kirzner does not advocate a growth theory where entrepreneurs appear as a stock-variable alongside other resources such as capital and labor, but this does not mean that his theory is irrelevant for the study of long-term growth.

It is instructive to seek a rationale for Kirzner's approach in the writings of two of the founding fathers of economics, Adam Smith and David Ricardo. Ricardo's (1821) theory describes output as a function of land, labor and capital, whereas Smith (1776) saw growing markets, division of labor and innovations as the engines of growth. It was the former approach that proved tractable to mathematical modeling and it provided the basis for neoclassical theory. In contrast, Kirzner's approach can be seen as an extension of that of Smith in that it accounts for the process by which innovations are introduced (Holcombe, 1998). In a very important sense this is growth, because the entrepreneurial discovery of opportunities means that previous errors, sources of suboptimal functionality of the market, are being corrected. This is why Kirzner (1963), in an early article "On the Premises of Growth Economics", says that the growth problem must "be placed in proper perspective as an allocation problem".

In this sense, Kirzner's contributions tell a story that can be related to neoclassical growth theory. Resource allocation and growth are two aspects of the same phenomenon (Kirzner, 1963). "Economics explains that where there are unexploited profit opportunities, resources have been misallocated [...] Entrepreneurship corrects [such] waste” (Kirzner, 1982). It is obvious that the dynamics of resource allocation provides a link between entrepreneurship and growth, even if it is not explicitly spelt out.

Another way of uncovering the link between entrepreneurship and growth is to note that Kirzner is attempting to return to Adam Smith’s conception of competition (Jakee and Spong, 2003). We have already seen that Kirzner sides with Hayek's (1948) criticism that perfect competition in equilibrium theory is synonymous with the absence of competition. In contrast, Kirzner argues that entering new firms are the agents that drive the competitive process, by introducing new goods and thereby also disciplining incumbent firms. The same decidedly “modern story” is mirrored in Baumol’s (1982) novel entry and contestability modeling, and 
subsequent models of entrepreneurial entry as the mover of the competitive process. A direct policy implication from this analysis is that stimulating competition and entry is preferred to the conventional policy prescriptions of antitrust interventions toward potential monopolists (Kirzner, 1973). Similar results follow from modern game-theoretic analyses of oligopoly firms (Horn and Persson, 2001). Audretsch et al. (2001) provide an excellent survey of this literature, and discuss its links to the Austrian tradition.

But we are still left in Kirzner's "thought experiment” of unchanging underlying variables. Does this not imply that we will reach a "steady state", beyond which growth cannot be explained? Apparently, Kirzner acknowledges a "continual change” in the UVs, but can he explain this change? Holcombe (1998) is an attempt to extend Kirzner's theory to long-run growth. Growth becomes a self-reinforcing process where entrepreneurial discoveries create new opportunities. An entrepreneurial discovery injects dynamism to the economy by changing the environment for other entrepreneurs. In a further elaboration, Holcombe (2003) points to the important role of the institutional setting in inspiring individuals to purposefully seek out opportunities (see also Douhan and Henrekson, 2007).

\section{Can Austrian and Neoclassical Economics Be Bridged?}

The neglect of entrepreneurship in modern analysis is a direct consequence of the general preoccupation with final equilibrium outcomes. (Kirzner, 1979, p. 5)

Q: Do you regard your entrepreneurial insight as a bridge between the Austrian and neoclassical worlds?

KIRZNER: The word "bridge" is a diplomatic word. I've been accused of turning Austrian economics into a footnote of neoclassical economics. I think that is incorrect. But I would accept the word "bridge." It is a bridge in the best sense of the term. (Interview, 1997)

Kirzner's disapproval of neoclassical theory can be understood as a critique of its inability to account for the entrepreneur. We have seen that there is, according to Kirzner, much more to this shortcoming than a simple neglect. In fact, the failure of neoclassical theory to account for what Kirzner calls the entrepreneurial element of human action is deeply rooted in its methodological approach and framework (Barreto, 1989; Bianchi and Henrekson, 2005). At the same time, we have also seen that Kirzner is much more favorable and close to mainstream economics than many other Austrian economists. Thus, irrespective of what 
seems like a fundamental difference, Kirzner has persistently approached and related his theories to mainstream economics. What kind of a bridge is this?

We have repeatedly stressed that the Austrian framework makes us able to see problems that have escaped the neoclassical analysis. Kirzner's contribution in this respect is no small achievement. We would argue that there is more. The discussion about different frameworks often neglects the fact that many problems only become visible from a particular approach. As a consequence, adherents to different approaches often have difficulties in understanding each other, even within the same discipline. In the light of this, Kirzner's most important contribution may be that he has made the Austrian school intelligible to other economics scholars. By aligning Austrian thinking to neoclassicism, the issues and problems have become visible to a much broader audience.

In this respect, Kirzner has not only contributed to a school within the discipline of economics but he has influenced the field of economics more broadly. The neglect of entrepreneurship in mainstream economics urged Kirzner to persist in arguing that as long as the standard economic theory has no room for individuals pursuing entrepreneurial opportunities, something of utmost importance has been omitted.

One might be tempted to say more about Kirzner's success in this respect. For instance, has his entrepreneur been successfully integrated into neoclassical theory? The answer is no, and probably it can never be integrated. And, most likely, this was never Kirzner's intention. But Kirzner has succeeded in developing a highly convincing account of the role of the entrepreneur and the entrepreneurial function in a market economy. In doing so, and doing it in a language to which mainstream economists can relate, he has also made evident important shortcomings of neoclassical theory. This will certainly continue to inspire mainstream economists to seek new and refine old methods and theories. There is no doubt that this makes Israel M. Kirzner a worthy recipient of The International Award for Entrepreneurship and Small Business Research.

\section{References}

Aghion, Philippe and Peter Howitt, 1998, Endogenous Growth Theory, Cambridge, MA and London: MIT Press. 
Aghion, Philippe and Peter Howitt, 1992, 'A Model of Growth Through Creative Destruction', Econometrica 60(2), 323-351.

Audretsch, David B., William J. Baumol and Andrew E. Burke, 2001, 'Competition Policy in Dynamic Markets’, International Journal of Industrial Organization 19(5), 613-634.

Barreto, Humberto, 1989, The Entrepreneur in Micro-Economic Theory: Disappearance and Explanation, London: Routledge.

Baumol, William J., 1968, 'Entrepreneurship in Economic Theory’, American Economic Review, Paper \& Proceedings 58 (2), 64-71.

Baumol, William J., 1982, 'Contestable Markets: An Uprising in the Theory of Industry Structure’, American Economic Review 72(1), 1-15.

Baumol, William J., 1990, 'Entrepreneurship: Productive, Unproductive, and Destructive’, Journal of Political Economy 98(5), 893-921.

Baumol, William J., 2002, The Free-Market Innovation Machine, Princeton and Oxford: Princeton University Press.

Bianchi, Milo and Magnus Henrekson, 2005, 'Is Neoclassical Economics still Entrepreneurless?’, Kyklos 58(3), 353-377.

Binenbaum, Eran, 1995, 'Kirzner’s Core concepts,' in Gerit Meijer (ed.), New Perspectives in Austrian Economics, London and New York: Routledge.

Burczak, Theodore, 2002, 'A critique of Kirzner’s Finders-Keepers Defense of Profit', Review of Austrian Economics 15(1), 75-90.

Colander, David, 2000, 'The Death of Neoclassical Economics', Journal of the History of Economic Thought 22(2), 127-143.

Demsetz, Harold, 1969, 'Information and Efficiency: Another Viewpoint', Journal of Law and Economics 12(1), 1-22.

Douhan, Robin and Magnus Henrekson, 2007, 'The Political Economy of Entrepreneurship: An Introduction', in Magnus Henrekson and Robin Douhan (eds.), International Library of Entrepreneurship Series: The Political Economy of Entrepreneurship, Northampton, UK: Edward Elgar.

Eliasson, Gunnar, 1996, Firm Objectives, Controls and Organization - The Use of Information and the Transfer of Knowledge within the Firm, Boston/Dordrecht/London: Kluwer.

Fu-Lai Yu, Tony, 2001, 'An Entrepreneurial Perspective of Institutional Change’, Constitutional Political Economy 12(3), 217-236.

Glancey, Keith S. and Ronald W. McQuaid, 2000, Entrepreneurial Economics, Houndsmill, Basingstoke and New York: Palgrave.

Gloria-Palermo, Sandye, 1999, Evolution of Austrian Economics: From Menger to Lachmann, Florence, KY, USA: Routledge.

Hayek, Friedrich von A., 1937, 'Economics and Knowledge', Economica 4(1), 33-54.

Hayek, Friedrich von A., 1945, 'The Use of Knowledge in Society', American Economic Review 35(4), 519-530. 
Hayek, Friedrich von A., 1980 [1948], Individualism and the Economic Order, Chicago: University of Chicago Press.

Holcombe, Randall G., 1998, ‘Entrepreneurship and Economic Growth’, Quarterly Journal of Austrian Economics 1(2), 45-62.

Holcombe, Randall G., 2003, 'The Origins of Entrepreneurial Opportunities', Review of Austrian Economics 16(1), 25-43.

Horn, Henrik and Lars Persson, 2001, 'The Equilibrium Ownership of an International Oligopoly', Journal of International Economics 53(2), 307-333.

Interview with Israel M. Kirzner, 1997, 'Between Mises and Keynes’, The Austrian Economics Newsletter, 17(1).

Jakee, Keith and Heath Spong, 2003, 'Praexeology, Entrepreneurship and the Market Process: A Review of Kirzner's Contribution', Journal of the History of Economic Thought 25(4), 461-486.

Kirzner, Israel M., 1960, The Economic Point of View: An Essay in the History of Economic Thought, Available online from The Library of Economics and Liberty, at http://www.econlib.org/library/NPDBooks/Kirzner/krzPV.html.

Kirzner, Israel M., 1963, 'On the Premises of Growth Economics', New Individualist Review, Summer, 20-28.

Kirzner, Israel M., 1969, 'Entrepreneurship and the Market Approach to Development', paper presented to the Mont Pelerin Society, Caracas, Sept. 1969. Also published as Chapter 7 in Israel M. Kirzner, 1979. Perception, Opportunity, and Profit, Chicago and London: University of Chicago Press.

Kirzner, Israel M., 1973, Competition and Entrepreneurship, Chicago: University of Chicago Press.

Kirzner, Israel M., 1978, ‘The Entrepreneurial Role in Menger’s System', Atlantic Economic Journal 6(3), 31-45.

Kirzner, Israel M., 1979, Perception, Opportunity and Profit, Studies in the Theory of Entrepreneurship, Chicago and London: University of Chicago Press.

Kirzner, Israel M., 1982, ‘The Theory of Entrepreneurship in Economic Growth', in C. A. Kent. David L. Sexton and K. H. Vesper (eds.), Encyclopedia of Entrepreneurship, Englewood Cliffs. N.J.: Prentice Hall.

Kirzner, Israel M., 1985, Discovery and the Capitalist Process, The University of Chicago Press: Chicago and London.

Kirzner, Israel M., 1995, 'The Subjectivism of Austrian Economics’, in G. Meijer (ed.) New Perspectives on Austrian Economics, London and New York: Routledge.

Kirzner, Israel M., 1997, 'Entrepreneurial Discovery and the Competitive Market Process: an Austrian Approach', Journal of Economic Literature 35(1), 60-85.

Kirzner, Israel M., 1999, 'Creativity and/or Alertness: A Reconsideration of the Schumpeterian Entrepreneur’, Review of Austrian Economics 11(1-2), 5-17.

Kirzner, Israel M., 2000, 'The Limits of the Market: the Real and the Imagined', in I. M. 
Kirzner (ed.) The Driving Force of the Market - Essays in Austrian Economics, Routhledge: London, 77-87.

Kirzner, Israel M., 2002, 'Comment on ‘A Critique of Kirzner’s Finders-Keepers Defence of Profit’, Review of Austrian Economics 15(1), 91-94.

Koppl, Roger, 2006, 'Austrian Economics at the Cutting Edge', Review of Austrian Economics 19(4), 231-241.

Lachmann, Ludwig, 1976, 'From Mises to Shackle: An Essay on Austrian Economics and the Kaleidic Society', Journal of Economic Literature 14(1), 54-62.

Leibenstein, Harvey, 1968, 'Entrepreneurship and Development', American Economic Review 58(2), 72-83.

Menger, Carl, 1892, 'On the Origins of Money’, Economic Journal 2(2), 239-255.

Mises, Ludwig von, 1949, Human Action: A Treatise on Economics (4 ${ }^{\text {th }}$ ed.), San Francisco: Fox \& Wilkes.

Nelson, Richard R. (ed.), 1993, National Systems of Innovation: A Comparative Study, Oxford: Oxford University Press.

Nelson, Richard R. and Sidney G. Winter, 2002, 'Evolutionary Theorizing in Economics', Journal of Economic Perspectives 16(2), 23-46.

Nelson, Richard R. and Sidney G. Winter, 1982, An Evolutionary Theory of Economic Change, Cambridge, MA: Harvard University Press.

Pelikan, Pavel, 1988, 'Can the Imperfect Innovation Systems of Capitalism be Outperformed?', in Giovanni Dosi et al., Technical Change and Economic Theory, London: Pintner.

Ricardo, David, 1912 [1821], The Principles of Political Economy ( $3^{\text {rd }}$ ed.), London: J. M. Dent.

Robbins, Lionel, 1984 [1932], An Essay on the Nature and Significance of Economic Science (3 ${ }^{\text {rd }}$ ed.), London: MacMillan.

Schumpeter, Joseph A., 1984 [1934], The Theory of Economic Development, New Brunswick: Transaction Publishers.

Segerstrom, Paul, 1991, 'Innovation, Imitation and Economic Growth', Journal of Political Economy 99(4), 807-827.

Smith, Adam, 1937 [1776], An Inquiry into the Nature and Causes of the Wealth of Nations, New York: Modern Library.

Smith, Vernon, 2003, 'Constructivist and Ecological Rationality in Economics', American Economic Review 93(3), 465-508.

Smith, Vernon L., 1962, ‘An Experimental Study of Competitive Market Behavior’, Journal of Political Economy 70(2), 111-137.

Stiglitz, Joseph E. and Andrew Weiss, 1981, 'Credit Rationing in Markets with Imperfect Information', American Economic Review 71(3), 393-410.

Stiglitz, Joseph E., 1994, Whither Socialism?, Cambridge, MA and England: MIT Press.

Vaughn, Karen I., 1992, 'The Problem of Order in Austrian Economics: Kirzner vs. Lachmann', Review of Political Economy 4(3), 251-274. 